\title{
Mixing of free-tropospheric air with the lowland boundary layer during anabatic transport to a high altitude station
}

\author{
C. Tsamalis ${ }^{\mathrm{a}, \mathrm{d}, \mathrm{e}, *}$, F. Ravetta $^{\mathrm{a}}$, F. Gheusi ${ }^{\mathrm{b}}$, H. Delbarre $^{\mathrm{c}}$, P. Augustin ${ }^{\mathrm{c}}$ \\ a UPMC Univ. Paris 06, CNRS (UMR 8190), LATMOS-IPSL, Paris, France \\ b UPS Univ. Toulouse 03, CNRS (UMR 5560), LA (Laboratoire d'Aérologie), Toulouse, France \\ ' Univ. Littoral Côte d'Opale E' Univ. Lille Nord de France, CNRS (UMR 8101), LPCA (Laboratoire de Physico-Chimie de l'Atmosphère), Dunkerque, France \\ ' Ecole Polytechnique, CNRS (UMR 8539), LMD-IPSL, Palaiseau, France \\ e Met Office, Exeter, United Kingdom
}

\begin{abstract}
High altitude stations are the only platforms allowing for continuous measurements of the free-troposphere composition, and monitoring of trends away from pollution sources. However, they are influenced by mountain breezes and convection that bring air from the lowland boundary layer up to the summits. In summer 2005, a field campaign involving in situ measurements and ozone lidars was organized in the Pyrenees to investigate the impact of such processes on in situ measurements at the Pic du Midi (PDM) high altitude station (2875 m a.s.l.). On June 17 and 19 , a plain-tomountain thermal circulation developed during the day. Observations show that direct transport of lowland air masses to PDM cannot account for ozone measurements at the station. Also, according to measurements, the PDM station did not directly sample the free troposphere. These two days were further investigated using a Lagrangian box model combining transport, photochemistry and mixing with the background troposphere. It was possible to reproduce and analyze ozone time series recorded at PDM, and quantify the partial mixing with free tropospheric air during the transport. A large fraction ( 43 to $86 \%$ ) of air from the lower free troposphere was found to contribute to the gas melange sampled at PDM, with the best agreement found for fractions $57 \%$ (resp. $74 \%$ ) on June 17 (resp. June 19).
\end{abstract}

\section{Introduction}

Mountain stations play an important role in the monitoring of tropospheric composition and trends at large scale. They are in practice the only platforms enabling continuous in situ measurements at high altitude. Such observatories are generally situated remotely from regional emission sources. Even though they are sufficiently elevated to stay above the top of the boundary layer developing over the neighbouring lowlands, the question of their representativeness with respect to the free troposphere at regional or larger scale is a major concern. For instance, Baltensperger et al. (1997) performed continuous

\footnotetext{
* Corresponding author at: Met Office, Exeter EX1 3PB, United Kingdom. E-mail address: christoforos.tsamalis@metoffice.gov.uk (C. Tsamalis).
}

aerosol measurements at the high Alpine site Jungfraujoch (3450 $\mathrm{m}$ a.s.l.). Their data demonstrated that this very elevated site is not always representative of the free troposphere. Indeed, meso- $\gamma$ to meso- $\beta$ scale transport processes in the local mountain boundary layer might influence in situ measurements.

Among these processes are the thermally-induced flows in valleys and along the slopes of mountains (Mendonca, 1969; Vergeiner and Dreiseitl, 1987; Schumann, 1990; Haiden, 2003). Such flows cover all the scales of the mountainous terrain, from the local slope to the whole mountain ridge, with different associated time-scales (Whiteman, 1990, 2000). Slope winds (Vergeiner and Dreiseitl, 1987) are produced by buoyancy forces induced by temperature differences between the air adjacent to the slope and air at the same altitude but outside the slope boundary layer. They are quasi-instantaneous responses to the 
surface energy budget (Whiteman, 2000). Along-valley winds (Rampanelli et al., 2004) and plain-mountain winds (Bossert and Cotton, 1994) are produced by horizontal pressure gradients that develop along valley axes, or between the mountain and the plain, as a result of temperature differences in the atmosphere in the valleys and over the plain. As much larger air volumes are involved, the onset of along-valley and plain-mountain winds is delayed by several hours with respect to the modification of the surface energy budget (Whiteman (2000); see Gheusi et al. (2011) for an illustration in a valley close to Pic du Midi, the observatory considered in this study).

Anabatic flows - up-slope, up-valley or up-mountain flows occur when the surface is heated, mostly by daytime and during the summer period when solar heating is maximum (Zaveri et al., 1995). Effects of upslope flows on measurements in high altitude stations were established by either climatological studies or dedicated campaigns. For instance, relatively high values of carbon monoxide in the mean diurnal variation observed at Jungfraujoch in the afternoon (Forrer et al., 2000) were identified as a signature of upward transport of air from lower levels. This was found to be maximum around $18 \mathrm{~h}$ (local time), and most pronounced in summer during anticyclonic conditions. A similar diurnal variation in condensation nuclei concentration (diameter $>10 \mathrm{~nm}$ ) was observed at Mt. Lemmon, Arizona (2790 $\mathrm{m}$ a.s.1.), with a strong maximum occurring in the afternoon (and a minimum in the early morning) due to thermal currents (Shaw, 2007). Elevated moist layers observed by balloon soundings in the lee of the Alps (Henne et al., 2005b) were caused by injection of low-level air in the lower free troposphere by daytime upward venting of the valleys. In general, upward transport to elevated locations results in a mix of free tropospheric and boundary layer air, the latter containing higher water vapour, aerosols and gaseous anthropogenic and natural surface emissions (Atlas and Ridley, 1996; Forrer et al., 2000).

The thermally-induced flows in complex terrain also affect ozone (Couach et al., 2003; Langford et al., 2010). At many high altitude observatories, a common observed feature is a diurnal ozone cycle, especially during the summer period, with minimum concentrations in the middle of the day and maximum during night: Mt. Mitchell, USA, $2006 \mathrm{~m}$ a.s.l. (Aneja et al., 1994), Mauna Loa, Hawaii, 3400 m a.s.l. (Oltmans and Levy, 1994), Izana, Canary Islands, 2370 m a.s.l. (Fischer et al., 1998), Jungfraujoch, Switzerland, $3580 \mathrm{~m}$ a.s.l. (Schuepbach et al., 2001), Mt. Cimone, Italy, 2165 m a.s.l. (Bonasoni et al., 2000; Fischer et al., 2003), Mt. Abu, India, $1680 \mathrm{~m}$ a.s.l. (Naja et al., 2003), Mt. Kenya, Africa, 3678 m a.s.l. (Henne et al., 2008), Mt. Whistler, Canada, $2182 \mathrm{~m}$ a.s.l. (Macdonald et al., 2011) and Pic du Midi, 2875 m a.s.l., France (Marenco, 1986; Gheusi et al., 2011). We qualify such cycles as opposite with regard to those usually observed at low-elevation stations (urban as well as rural, e.g. Kleinman et al., 1994; Kalabokas et al., 2000; Millan et al., 2000) where surface ozone is mainly driven by solar radiation. The amplitude of opposite cycles is however much lower (a few ppb).

Upward transport of boundary-layer air and mixing in ambient free tropospheric air during daytime is the explanation given by most authors for afternoon maxima observed at high altitude stations for boundary layer tracers (water vapour, aerosols, $\mathrm{CO}$, etc.). The same explanation accounts at least qualitatively for the opposite cycle of ozone, since the mean ozone stratification in the lower troposphere is reversed compared to boundary layer tracers (ozone levels increase with height in the first kilometres of the atmosphere, e.g. Chevalier et al. (2007)). Therefore, mixing of low-level ozone-poor air in ozone-rich free-tropospheric air results in an ozone decrease.

According to this explanation, ozone time series should be in phase opposition with the concentrations of the boundary-layer tracers. However, Marenco (1986) observed at Pic du Midi (hereafter PDM) a delay of about $4 \mathrm{~h}$ between the ozone minimum in the late morning and the $\mathrm{CO}$ and water vapour maximum in the afternoon from March to September 1982. Gheusi et al. (2011) confirmed a similar behaviour in more recent observations at PDM. This is also the case for the data from Jungfraujoch (Zellweger et al., 2003).

Marenco (1986) interpreted this delay as the influence of photochemical formation of ozone in the air rising from lower layers up to the station. He proposed a simple model where air sampled at the station during the day is a mix from two reservoirs with two constant (but different) concentrations: the free troposphere and the boundary layer. Since CO reactivity is negligible over the diurnal time scale, the proportion of air from each reservoir was estimated from the diurnal cycle of this tracer. Ozone net production was estimated as the difference between the observed concentration and the value obtained assuming mixing only. This model has important limitations, mainly because it is only based on local measurements at the station. Many assumptions are needed to assign values to the background concentrations in each reservoir. In particular, the assumption of $100 \%$ of boundary layer air at the time of CO maximum is questionable. Another shortcoming is that ozone concentration in the boundary-layer reservoir is highly variable during the day but this was not taken into account in Marenco (1986).

Current meteorological models are capable of simulating the atmospheric flows over complex terrain rather adequately (e.g. Szintai et al., 2010; Lesouef et al., 2011; Vosper et al., 2013). Due to modern capabilities simulations with high horizontal resolution (i.e. equal or lower than $1 \mathrm{~km}$ ) are possible for large domains, covering the whole mountain chain, even if they remain computationally expensive. On the contrary, this is not the case for chemical transport models, with the emissions being the major problem for this. Indeed, the emission inventories are not available at such high horizontal resolution, especially away from urban areas, like mountain regions. Also, the emission inventories still have non-negligible uncertainties (e.g. Zyrichidou et al., 2013). As the focus of this paper is ozone concentration, rather than meteorological parameters like temperature or wind, in order to minimize the uncertainties arising from the emissions, a Lagrangian box model will be used for the determination of the processes that govern the ozone evolution. To the best of our knowledge this is the first time that the anabatic transport to a high altitude station has been investigated through the modelling of a chemical tracer like ozone.

The field campaign Pic 2005 (Gheusi et al. (2011); see Section 2 for a brief summary) provides in situ ozone and low-level tracer measurements at different locations and altitudes around the Pic du Midi station, as well as vertical profiles of ozone retrieved from lidar observations. This gives the opportunity to refine the concepts proposed by Marenco (1986) using (i) background ozone values derived 
from observations and (ii) a Lagrangian box model to simulate the upward transport, photochemistry and mixing with free-tropospheric ambient air of an air parcel rising from the plain boundary layer up to the observatory. This model has been run for a one-day intensive observation period (June 17), during which a clear opposite ozone cycle was observed at PDM. CO variation at PDM will not be investigated in the same way because we do not have any measurement of $\mathrm{CO}$ in the background free troposphere on that day.

A short description of the campaign is given in Section 2, as well as a presentation of meteorological context and the characterization of the plain-to-mountain flow. In Section 3, the ozone observations are discussed. In Section 4, the chemicalLagrangian box simulation is presented and results for June 17 are discussed. The model application for a second day intensive observation period is presented in Section 5. Conclusions are given in Section 6.

\section{Pic 2005 campaign and June 17 case study}

The PDM observatory is located on the northern side of Pyrenean Mountains in south-western France (Fig. 1), a rural region with low population and industry density. The Pic 2005 field campaign took place in June and July 2005 (Gheusi et al., 2011). The main goal of this campaign was to study chemical and dynamical processes accounting for the observed ozone variability at PDM. This paper focuses on the influence of transport from the lowland boundary layer on ozone measurements at PDM. The two main sites were the PDM observatory and the Atmospheric Research Center of Lannemezan (CRA), a piedmont site on a plateau (600 $\mathrm{m}$ a.s.l.) $28 \mathrm{~km}$ north-east of PDM. CRA is representative of the low-level atmosphere over the French plain to the foot of the Pyrenees (Fig. 1). Although, during the Pic 2005 campaign there were no other measurements in the lowland boundary layer to support this assumption, note that the low altitude station Chiroulet, located in the Lesponne valley $4 \mathrm{~km}$ north-west of PDM, showed similar CO levels to CRA (see Gheusi et al., 2011). In addition, rural sites such as CRA are known to have representativeness at the regional scale at least (e.g. Henne et al., 2010). Indeed, the homogeneous composition of the lowland boundary layer for the area around CRA can be seen on the analyzed maps of surface ozone from the operational air quality forecasting and analysis system PREV'AIR (Rouil et al., 2009, http://www.prevair.org) (maps for the Pic 2005 period are also provided by Gheusi et al. (2011)). Six intensive observation periods (IOPs) were organized. Here, most emphasis is given to June 17. This choice was made due to: i) the presence of fair weather conditions, which favour the development of thermal breezes, ii) the establishment of thermal breezes, indicated by the inversed diurnal ozone cycle at PDM and the wind direction change at CRA, and iii) the direct connection in the free troposphere between CRA and PDM by the wind (see results below and Gheusi et al. (2011)). In Section 5, the June 19 case study will be examined to support results found for June 17.

The instrumentation is described in detail in Gheusi et al. (2011). In situ measurements of ozone, carbon monoxide and meteorological parameters were registered at all sites. The vertical distribution of ozone at CRA was measured in the boundary layer by the mobile lidar ULCO (Delbarre et al., 2005) and in the lower troposphere by the lidar ALTO (Ancellet and Ravetta, 1998, 2003). Also, ALTO provided the vertical distribution of aerosols through the scattering ratio at $316 \mathrm{~nm}$, which is the ratio of total backscattering (by molecules and aerosols) to

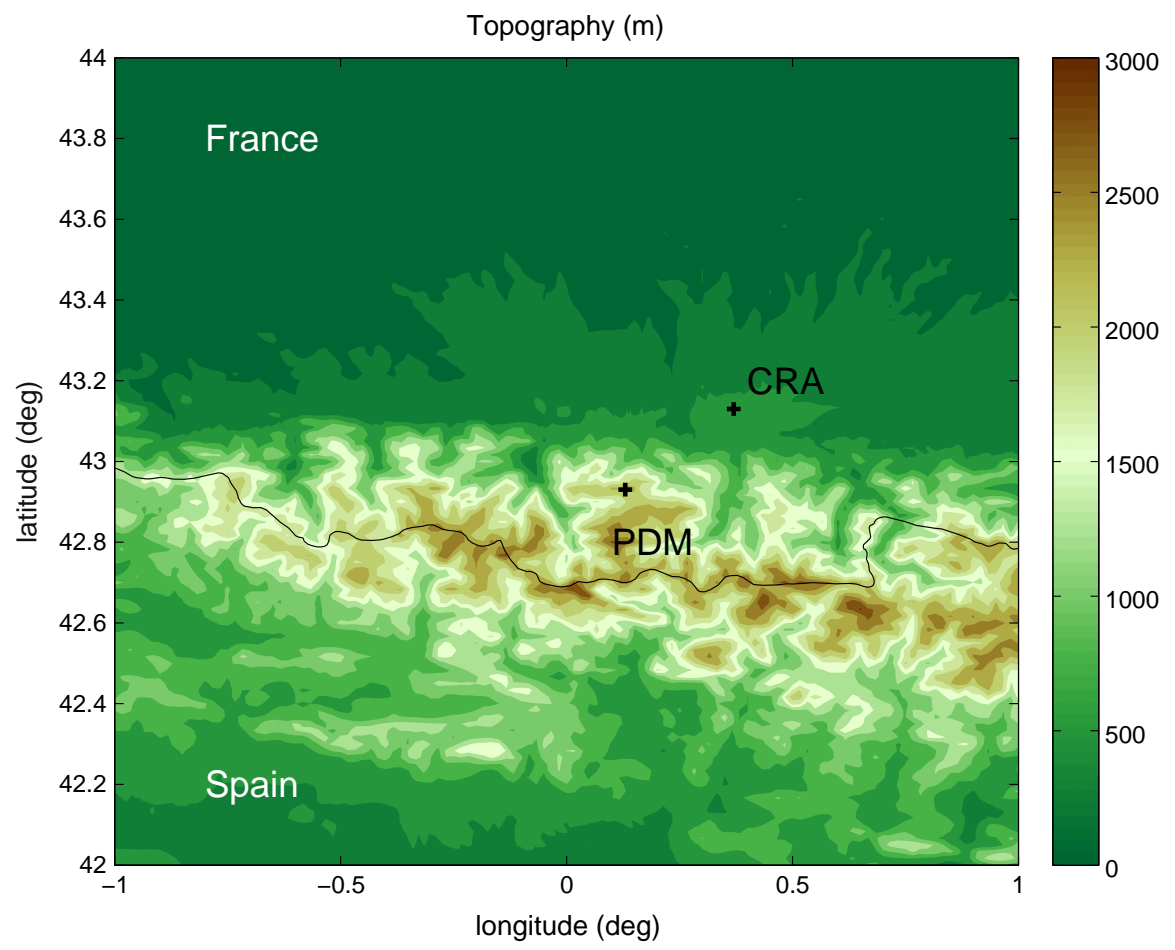

Fig. 1. Topography (in metres a.s.l.) around the PDM and the CRA sites. 
molecular backscattering (Ancellet and Ravetta, 2005; Ravetta et al., 2007). Finally, the VHF radar (Campistron et al., 1999) registered the wind in the vertical range $2-16 \mathrm{~km}$ above CRA.

On June 17, anticyclonic conditions were prevailing, favouring the development of thermal breezes (Forrer et al., 2000; Lugauer et al., 2000). The area was embedded in a pressure ridge driving a north-easterly mid-tropospheric flux (Fig. 2a). The VHF radar at CRA confirmed this observation and also showed a change in wind direction, the wind turning northerly after 15 UTC (Fig. 2b). Surface wind direction at CRA (Fig. 2c) changed from south-east at night to north-east during daytime. This was identified by Noilhan et al. (1982) as the thermal breeze system between the plain and the Pyrenean Mountains. At PDM, the wind was north-easterly at night and in the morning, southerly and weak (below $2 \mathrm{~m} / \mathrm{s}$ ) in the afternoon, and northerly in the evening. These wind observations at both sites are signatures of thermally induced circulations at all scales in the area (Gheusi et al., 2011). The present study focuses on the plain-to-mountain wind system that brings air from the forelands to PDM during daytime. However, because both upslope and up-valley breezes contribute to upward flow with the plain-to-mountain breeze at the level of PDM (but at different scales), the term anabatic is used to denote the total effect of all breezes (especially after the arrival of the plain-to-mountain breeze at PDM) as it is not restricted to a specific scale.

The plain-to-maintain breeze starts to develop at 6 UTC, as indicated by the wind direction change at CRA (Fig. 2c). This is two hours later after the sunrise occurring at 4 UTC during this period of the year. As the plain-to-mountain breezes have a rather large spatial scale, they have a slow response to thermal forcing in comparison to the other types of breezes (see Introduction). After 8 UTC the wind direction at CRA is NE and remains constant until 19 UTC, turning to
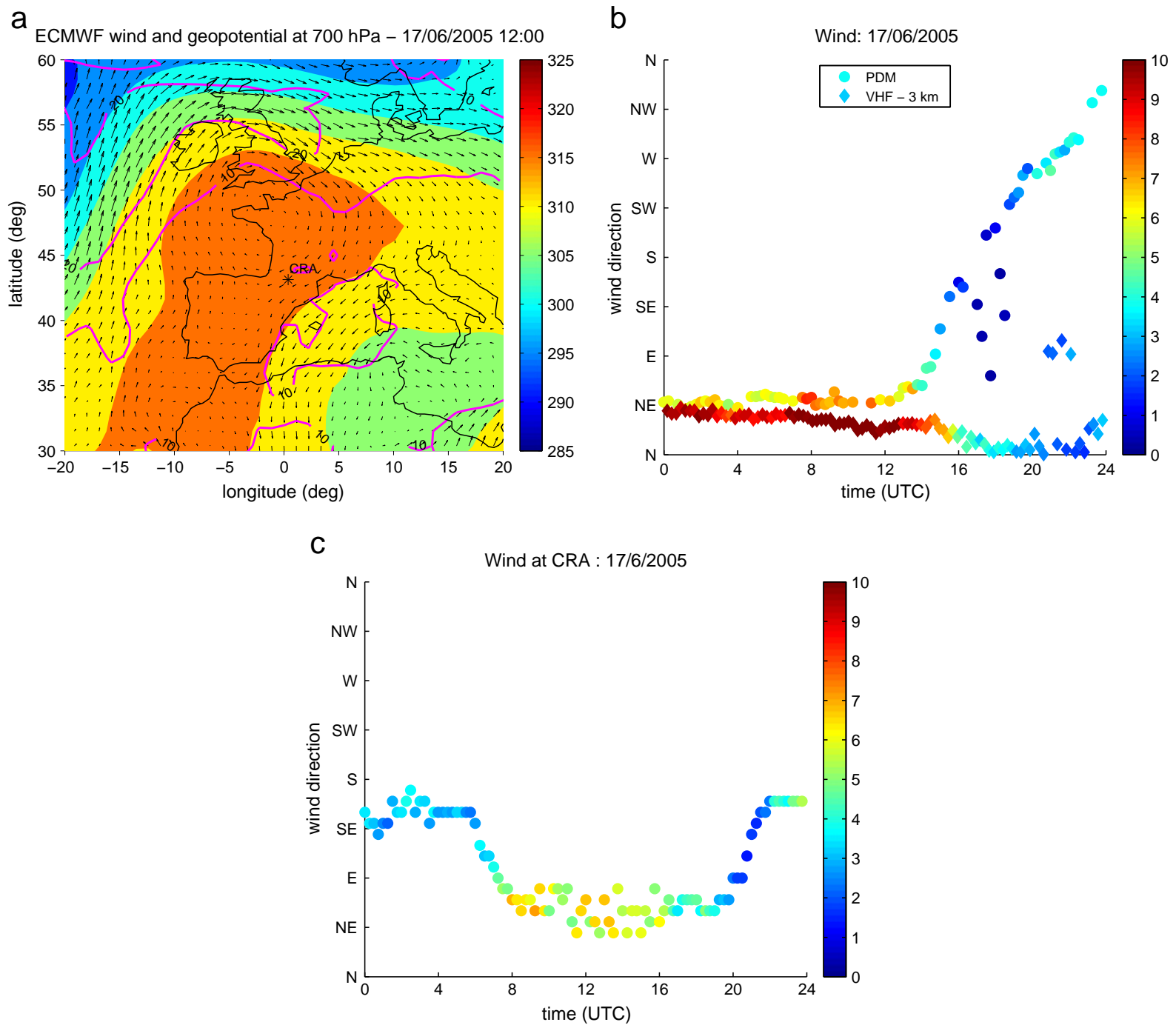

Fig. 2. (a) ECMWF analysis on $17 / 6 / 2005$ at $700 \mathrm{hPa}$ of geopotential height (colorscale in dam) and wind speed (magenta isolines in $\mathrm{m} / \mathrm{s}$ ). The location of CRA is plotted with a star. (b) Wind direction and wind speed (colorscale in m/s) at PDM (circles) and at an altitude of $3 \mathrm{~km}$ a.s.l. above CRA (diamonds) from the VHF radar on June 17. (c) Ground level wind direction and wind speed (colorscale in $\mathrm{m} / \mathrm{s}$ ) at CRA (circles) on June 17. 
$S$ after 21 UTC. Thus, the plain-to-mountain breeze starts to develop at 6 UTC and is well established by 8 UTC. This is in agreement with the median results of the Pic 2005 campaign (for thermally driven conditions), indicating that the CRA wind direction change starts at about 6 UTC and is well established by 8 UTC, with the wind direction staying NE until 18 UTC (Gheusi et al., 2011). On the other hand, in the free-troposphere at $3 \mathrm{~km}$ above CRA (see next section for the boundary layer height) the synoptic flow is NE from 0 UTC to 12 UTC (turning slowly to $\mathrm{N}$ afterwards) (Fig. 2b), thus without wind direction change neither between 6 and 8 UTC nor between 19 and 21 UTC, as seen at the surface. The wind speed of plain-to-mountain breezes is normally weak(approximately $2 \mathrm{~m} / \mathrm{s}$ ) (Whiteman, 2000), thus the fairly strong wind observed in the free-troposphere and at the surface (mostly between 8 and 16 UTC) points towards another process taking place during this period, e.g. downward entrainment of momentum as the convective boundary layer grows. Indeed, one can notice the increase of the boundary layer height after 8 UTC, which is found at $1.3 \mathrm{~km}$ (Fig. 4b, see next section). However, the presence of other atmospheric processes (mostly after $8 \mathrm{UTC}$ ) is not contradictory to the development of a plain-to-mountain system started at 6 UTC and well established after 8 UTC.

The development of this system was simulated with the mesoscale non-hydrostatic Meso-NH model (CNRS, 2009). A tracer of the French Planetary Boundary Layer (PBL) was used to follow the plain-to-mountain transport. The horizontal resolution of the simulation is $3 \mathrm{~km}$, while the vertical resolution is stretched from $40 \mathrm{~m}$ near the ground to $500 \mathrm{~m}$ at an altitude of $26 \mathrm{~km}$ a.s.l., with a terrain-following grid. These resolutions are appropriate to capture the mesoscale plain-to-mountain circulation system and to estimate the travel time of air masses. Indeed, similar model resolution has been used to reproduce the general flow structure towards the Alps during a summer day (Weissmann et al., 2005). Further information about this simulation can be found in Chevalier (2007) and Gheusi et al. (2011). Initially, the French PBL tracer is a 500-m deep terrainfollowing layer, covering the French part of the simulation domain, but with an absolute upper limit at $1500 \mathrm{~m}$ above sea level. Therefore the layer is thinner where terrain elevation exceeds $1000 \mathrm{~m}$. The initial value of the tracer was set to zero outside this surface layer and for all altitudes above $1500 \mathrm{~m}$ a.s.l. Inside the surface layer, the tracer is forced at every time step to take the value of 1000 (arbitrary unit).

The south-north vertical cross sections in Fig. 3 correspond respectively to the arrival (11 UTC) of the very first low level air masses at PDM, to the maximum of the plain-to-mountain (anabatic) flow (17 UTC) and to the beginning of the mountainto-plain (katabatic) flow (21 UTC). Low level air reaches PDM about 5 h after the onset of the plain-to-mountain system (6 UTC at CRA, Fig. 2c). This is consistent with the numerical simulation by de Wekker et al. (1998) finding a transport time larger than $4 \mathrm{~h}$ for the upward thermal flow to reach the summit of an idealized topography. In the idealized numerical simulations of Kimura and Kuwagata (1993), the time needed by the upward flow to attain the mountain summit from the plain was $3 \mathrm{~h}$. For real conditions, this advection time depends on the meteorological conditions and on the features of the complex mountainous terrain. Note also that $5 \mathrm{~h}$ is the time needed to travel $28 \mathrm{~km}$ (the distance of CRA to PDM) at $1.6 \mathrm{~m} / \mathrm{s}$. This speed is consistent with typical advection velocities $(1.5 \mathrm{~m} / \mathrm{s})$ from the Alpine foreland towards the Alps in similar weather conditions (Henne et al., 2004) and with typical wind speed for plain-to-mountain breezes (about $2 \mathrm{~m} / \mathrm{s}$ ) (Whiteman, 2000).

According to our simulation, the largest influence of the low atmosphere over the plain on the measurements at the summit is expected in the afternoon around 17 UTC (Fig. 3b). After sunset, opposite katabatic flows develop (Fig. 3c). PDM may experience the influence of residual layers (Zaveri et al., 1995), but is no longer under the direct influence of lowland air masses.

\section{Ozone observations}

The former section has shown that a thermally driven upward flow develops on June 17, the PDM station being influenced by air masses from the foreland boundary layer, mostly in the afternoon. The next step is to investigate the effect of this flow on ozone measurements at PDM.

Fig. 4a presents a synthetic image of ozone measurements in the campaign area on June 17. The vertical cross section is produced using ULCO measurements $(0.6-1.0 \mathrm{~km})$ and ALTO measurements (1.3-3.5 km). The baseline represents the ozone in situ measurements at CRA, while in situ ozone observations at PDM are plotted at the altitude of $2.7 \mathrm{~km}$ for direct comparison with the lidar. From the ground up to the top of the aerosol layer (1.5-2 km), ozone concentration is about $40-45 \mathrm{ppb}$, while above the top of the aerosols layer it drops to 20-30 ppb. In addition, there are two ozone layers above $3 \mathrm{~km}$ (6-7 and 10-14 UTC). Their origin is not local (Gheusi et al., 2011) and will not be investigated here. There are almost no aerosols in the free troposphere, as the scattering ratio is close to 1 above $2 \mathrm{~km}$ a.s.l. (Fig. 4b).

Ozone measurements present a minimum around noon at PDM (Figs. 4a, 5a). This is indicative of upslope air transport to PDM. Taking the time intervals 8-18 UTC and 22-5 UTC to select day and night periods, the difference between day and night ozone mean levels at PDM on June 17 is 4 ppb (Table 1).

Fig. 5a shows that in situ ozone measurements at PDM are higher than ALTO ozone measurements above CRA at the same altitude (red line and green diamonds, respectively). The mean difference is about $13 \mathrm{ppb}$ (Table 1). Since the wind is blowing north-easterly at this altitude above the two sites (Fig. 2b), both stations could have sampled the same free-tropospheric air mass. This was not actually the case. Even with a time shift of 1-2 h to account for horizontal advection, ozone time series at PDM and above CRA do not coincide.

At CRA, surface ozone daytime mean value is $16 \mathrm{ppb}$ higher than its value at night (Table 1 ). There is a sharp ozone increase in the morning between 6 and 9 UTC (Fig. 5b). Photochemical production in the boundary layer may contribute to this increase. However at 6 UTC, an ozone-rich layer visible around $1.5 \mathrm{~km}$ a.s.l. lies above the nocturnal boundary layer (Fig. 4a). Its entrainment by mixing within the developing boundary layer in the morning can also account for this ozone jump (Neu et al., 1994; Zhang and Rao, 1999). Indeed, Fig. 5b shows agreement after 8 UTC between ALTO measurements at $1.3 \mathrm{~km}$ a.s.l., ULCO mean measurements within the PBL (0.6-1.0 km a.s.l.) and surface measurements. This suggests a well-mixed PBL developed up to the altitude of the ozone-rich layer after 8 UTC. Entrainment of ozone-rich air from above during the PBL 
a

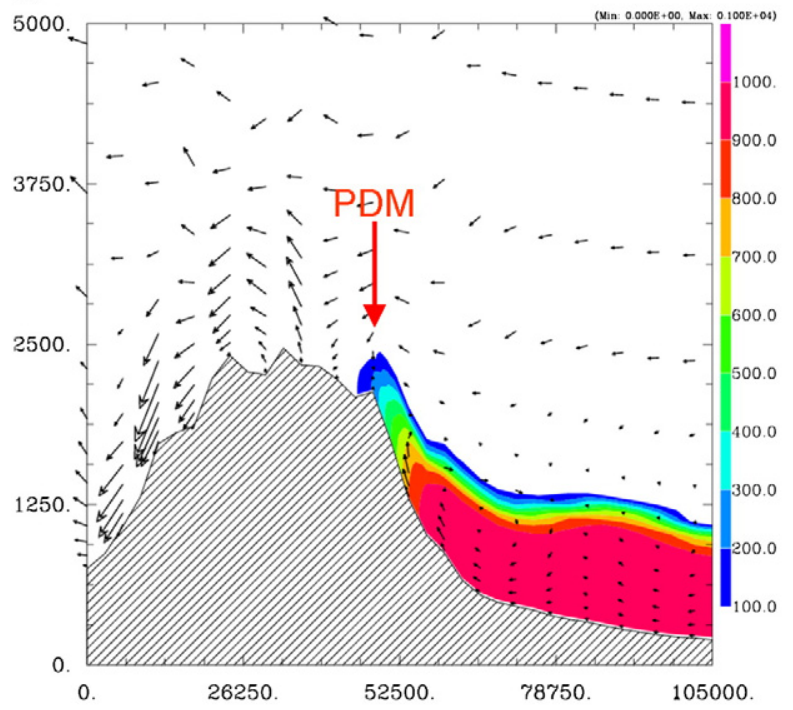

b

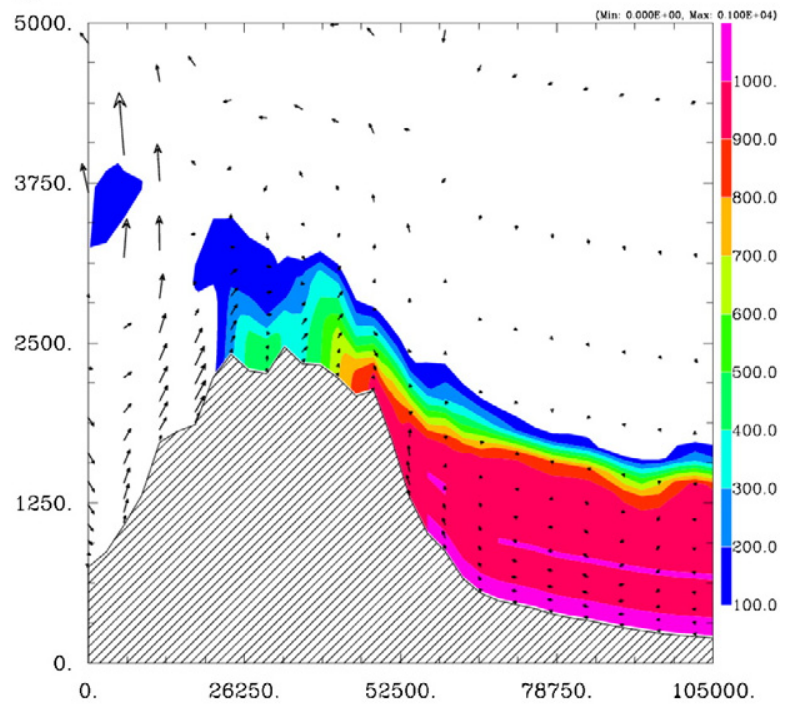

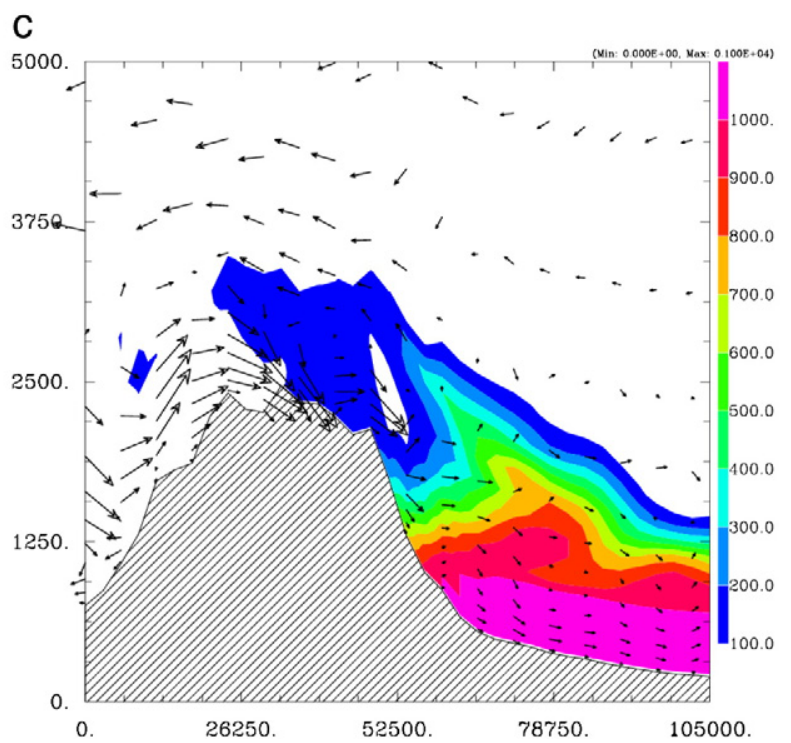

Fig. 3. Vertical south-north cross section of the French PBL tracer (see text for its definition) from MesoNH model on 17/6/2005 at (a) 11 UTC, with a red arrow pointing towards PDM location, (b) 17 UTC and (c) 21 UTC.

development is therefore likely to explain the surface ozone jump.

Over flat terrain the aerosol layer coincides with the convective boundary layer (Seibert et al., 2000). Lidar backscattering ratios and the inflection point method were used for the determination of the PBL height (Menut et al., 1999). Results are shown in Fig. 4b. The PBL did not develop above $2 \mathrm{~km}$ a.s.l. well below the altitude of the Pyrenean high summits (in agreement with Dubosclard et al. (1983) who reported afternoon PBL heights up to $1.8 \mathrm{~km}$ a.s.l. from radiosoundings in June above CRA). Consistently, the ozone in situ measurements did not match at CRA and PDM during daytime since the sites did not sample the same layer.

In summary, the PDM ozone measurements were neither representative of the free troposphere nor the lowland boundary layer. Still, these measurements were influenced by thermal upward transport of air from the low layers and possibly from the plain (Section 2). A modelling study combining chemistry, mixing and transport will now be used to investigate this process.

\section{Chemical box modelling with mixing}

In this section, we use a Lagrangian chemical box model with a simple mixing parameterization, to further investigate ozone variability at PDM, when anabatic flow brings air masses from the plain to the summit. The transport is not direct and mixing of air from the plain with the background atmosphere occurs before reaching the summit. With this model, we want to i) reproduce ozone time series at PDM in the late 

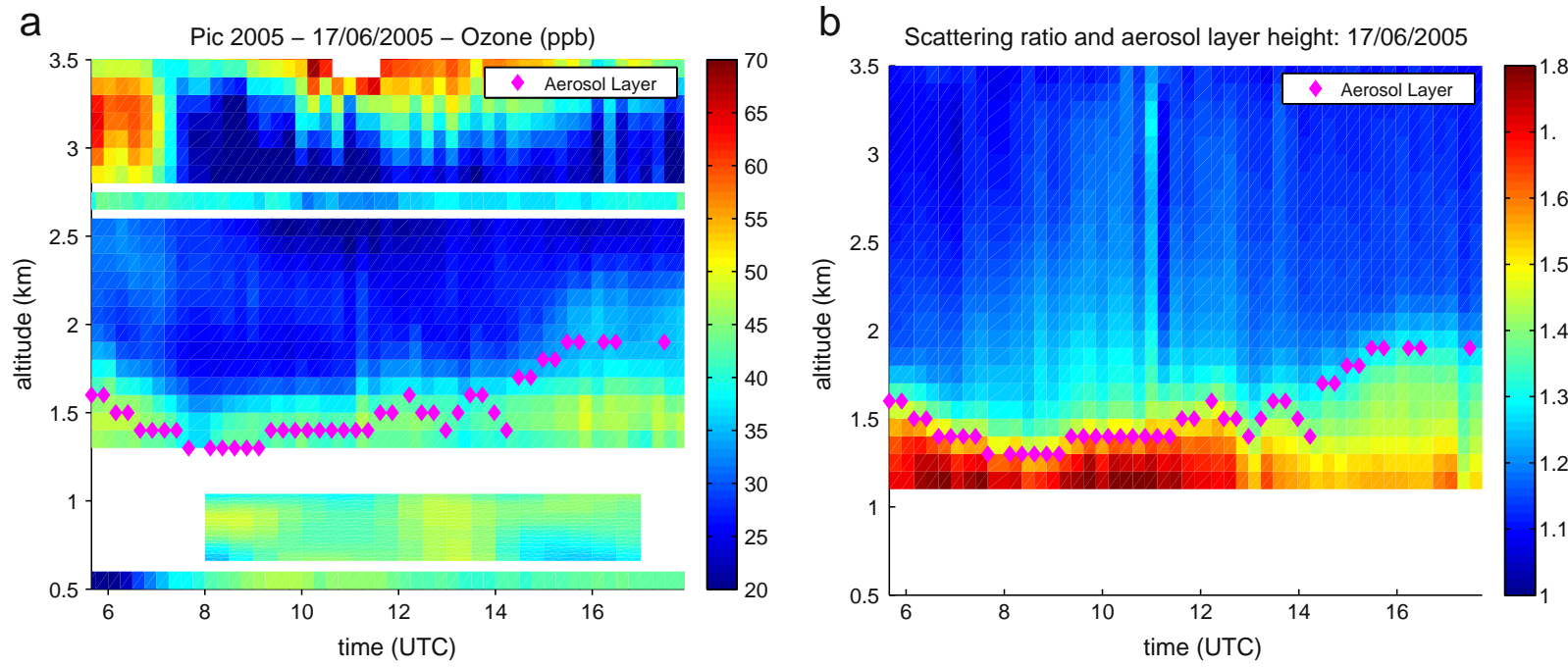

Fig. 4. (a) Ozone mixing ratio (ppb) measured at CRA by lidars ULCO (0.6-1.0 km) and ALTO (1.3-3.5 km) on 17/6/2005. The baseline shows in situ ozone measurements at CRA, while in situ ozone measurements at PDM are plotted at the altitude of $2.7 \mathrm{~km}$. Magenta diamonds indicate the top of the aerosol layer. (b) Aerosols scattering ratio at $316 \mathrm{~nm}$ and the top of the aerosol layer (magenta diamonds) as seen by ALTO on the same day.

morning and the afternoon and ii) quantify mixing during upward transport.

\subsection{Model description and mixing parameterization}

Transport and reactivity of air masses uplifted from the plain (CRA) to the summit (PDM) are simulated with the Lagrangian photochemical box model CITTYCAT. This model transports an air parcel along a prescribed trajectory and relies on a detailed chemical scheme including hydrogen, oxygen, nitrogen and methane chemistry (Wild et al., 1996). At each 5-min time step the chemical composition of the parcel is updated considering its position (pressure, temperature) and the following processes: chemistry, surface emissions (from EMEP database), deposition and mixing with the background atmosphere (Evans et al., 2000).

For this case study, CITTYCAT is initialized with in situ measurements of ozone, carbon monoxide, and water vapour (see Table 2). All other chemical species are initialized using the output of a simulation of the Pic 2005 campaign area by the mesoscale chemical and transport model CHIMERE (Vautard et al., 2001). Table 2 presents the concentrations of most important chemical species issued from CHIMERE simulation.

Table 1

Mean values of ozone (ppb) with their standard deviations at PDM and CRA, during night time (22-5 UTC) and daytime (8-18 UTC), with comparison with the ALTO measurements during daytime at $2.9 \mathrm{~km}$ and 1.3 or $1.5 \mathrm{~km}$ on June 17 and 19.

\begin{tabular}{cllll}
\hline Day & \multicolumn{2}{c}{ June 17} & \multicolumn{2}{c}{ June 19} \\
\hline In situ & PDM & CRA & PDM & CRA \\
Night & $41 \pm 3$ & $27 \pm 8$ & $48 \pm 6$ & $51 \pm 11$ \\
Day & $37 \pm 3$ & $43 \pm 2$ & $52 \pm 2$ & $62 \pm 7$ \\
ALTO & $2.9 \mathrm{~km}$ & $1.3 \mathrm{~km}$ & $2.9 \mathrm{~km}$ & $1.5 \mathrm{~km}$ \\
Day & $24 \pm 6$ & $42 \pm 2$ & $63 \pm 7$ & $70 \pm 5$ \\
\hline
\end{tabular}

Transport from CRA to PDM is modelled considering vertical advection of an air parcel and mixing with background air (Fig. 6). Simulations start at $950 \mathrm{hPa}$ (CRA) and end at $730 \mathrm{hPa}$ (PDM). The vertical transport is modelled by an adiabatic ascent with constant vertical speed between the two levels.

For each simulation, the final ozone value, $C_{O_{3}}^{P D M}\left(t_{0}+\Delta t\right)$, represents the ozone concentration at PDM. This value depends on the initial ozone concentration at CRA, ozone photochemistry during the transport, and three parameters: total travel time $\Delta t$, mixing time $\tau_{\text {mix }}$ and ozone background value $\mathrm{C}_{O_{3}}^{\text {bg }}$ (Fig. 6):

$\mathrm{C}_{O_{3}}^{P D M}\left(t_{0}+\Delta t\right)=\mathrm{C}_{O_{3}}^{C R A}\left(t_{0}\right)+\int_{t_{0}}^{t_{0}+\Delta t}\left[\left.\frac{\mathrm{dC}_{O_{3}}}{\mathrm{~d} t}\right|_{\text {mix }}+\left.\frac{\mathrm{dC}_{O_{3}}}{\mathrm{~d} t}\right|_{c h e m}\right] \mathrm{d} t(1)$

where $\mathrm{C}_{O_{3}}^{\mathrm{CRA}}\left(t_{0}\right)$ is the initial concentration at CRA. Mixing is modelled as elastic relaxation (time constant $\tau_{\text {mix }}$ ) of parcel concentrations towards background values:

$\left.\frac{\mathrm{dC}}{\mathrm{d} t}\right|_{\text {mix }}=-\frac{1}{\tau_{\text {mix }}}\left[\mathrm{C}(t)-\mathrm{C}^{b g}\right]$.

Several simulations started hourly at CRA were used to generate ozone time series at PDM (Fig. 7). The three parameters can be adjusted in order to match the simulated ozone time series with the observed series at PDM. However, constraints exist on $\Delta t$ and $C_{O_{3}}^{b g}$. Given the result of Section 2, $\Delta t$ should be around $5 \mathrm{~h}$. The lidar profiles suggest an ozone background value of about $30 \mathrm{ppb}$ in the $1.5-2.5$ altitude range (Fig. 6). 
a

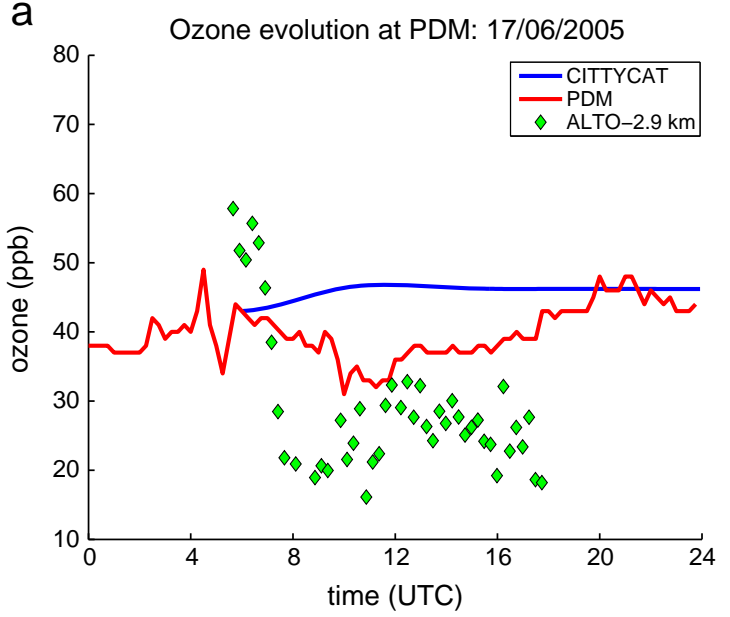

b

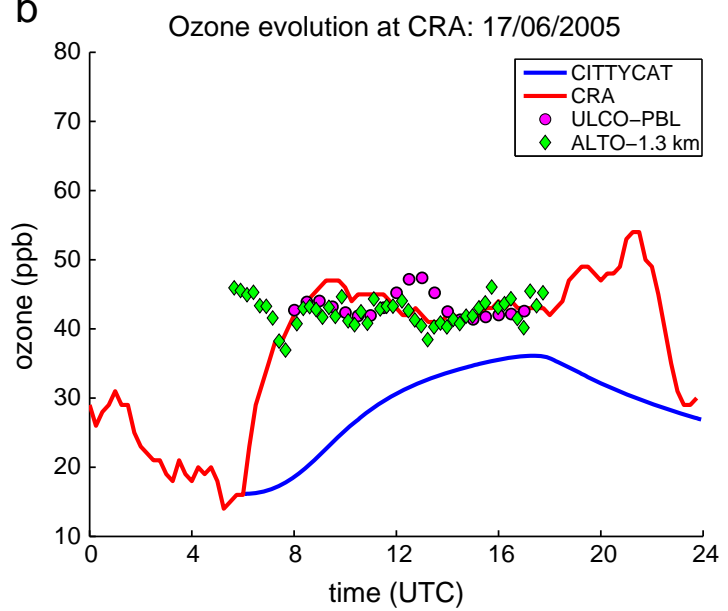

Fig. 5. (a) Ozone data on June 17: in situ measurements at PDM (red line), simulations by CITTYCAT model at PDM (blue line), ALTO measurements above CRA at an altitude of $2.9 \mathrm{~km}$ (green diamonds). (b) Same as figure (a) but at CRA. Magenta circles show ULCO mean measurements within the PBL (0.6-1.0 km), while ALTO measurements are now taken at an altitude of $1.3 \mathrm{~km}$.

\subsection{Method to estimate mixing}

Following Marenco (1986), we define $f$ as the fraction of air from the lowland boundary layer incorporated in the mix sampled at PDM. $\Delta t$ and $\tau_{\text {mix }}$ are adjusted in order to match the simulated ozone time series (i.e. $\mathrm{C}_{\mathrm{O}_{3}}^{P D M}\left(t_{0}+\Delta t\right)$ obtained from a series of varying $t_{0}$ ) with the observed series at PDM, by taking into account the existing constraints on $\Delta t$. This provides best estimates for $\Delta t$ and $\tau_{m i x}$.

For any inert tracer, we have $\left.\frac{\mathrm{dc}}{\mathrm{d} t}\right|_{\text {chem }}=0$. In this case by using Eq. (2), Eq. (1) takes the analytical solution:

$C^{P D M}\left(t_{0}+\Delta t\right)=f \times C^{C R A}\left(t_{0}\right)+(1-f) \times C^{b g}$

where

$f=\exp \left(-\Delta t / \tau_{\text {mix }}\right)$.

$f$ is thus estimated from Eq. (4), using the best values found for $\Delta t$ and $\tau_{\text {mix }}$. Over the considered time range, it should be possible to directly estimate $f$ from CO observations and Eq. (3). But in our case the background concentration $\mathrm{C}_{\mathrm{CO}}^{b g}$ is not given by our data set, and assumptions would thus be needed (e.g. using a value from a climatology or a model). Working with ozone and Eq. (1) was preferred since $C_{O_{3}}^{b g}$ is directly estimated from a lidar profile (Fig. 6).

\subsection{Results}

Here, the model is run for the case of June 17. Recall that we are attempting to establish a direct connection between CRA and PDM. Rather, the CRA observations are regarded as representative of the French boundary layer near the Pyrenees (see Section 2).

\subsubsection{Chemistry without transport and mixing}

The box model is first used without vertical transport and mixing in order to estimate the net ozone production in the free troposphere at the height of PDM $(730 \mathrm{hPa})$ and in the boundary layer at CRA (950 hPa). In both cases the temperature is held constant during the simulation. For the free troposphere, the ozone concentration at 6 UTC at PDM is used as the initial condition (Fig. 5a and Table 2). The daily average net ozone production rate, from 6 UTC to 24 UTC, is $0.2 \mathrm{ppb} / \mathrm{h}$, in accordance with previous studies at high altitude sites. At Mt. Cimone, Fischer et al. (2003) calculated from observations a positive net ozone production of $0.1-0.3 \mathrm{ppb} / \mathrm{h}$ during June, while at Jungfraujoch, Zanis et al. (2000) calculated a net ozone production of $0.27 \mathrm{ppb} / \mathrm{h}$ from their model and $0.13 \mathrm{ppb} / \mathrm{h}$ from their observations during spring. In the lower free troposphere above the Alps, Henne et al. (2005a) reported a net ozone

\section{Table 2}

Mixing ratios of most important chemical species used in the Lagrangian box simulations of June 17. The first column provides the free tropospheric (FT) background values (constant in time). The second column corresponds to PDM concentrations at 6 UTC. The last 3 columns provide the initial values at CRA at different times of the day. Ozone and carbon monoxide concentrations come from measurements, but the others are from CHIMERE model (see text).

\begin{tabular}{lrrrrr}
\hline Species & FT & $\begin{array}{c}\text { PDM } \\
6 \text { UTC }\end{array}$ & $\begin{array}{c}\text { CRA } \\
6 \text { UTC }\end{array}$ & $\begin{array}{c}\text { CRA } \\
9 \text { UTC }\end{array}$ & $\begin{array}{c}\text { CRA } \\
12 \text { UTC }\end{array}$ \\
\hline $\mathrm{O}_{3}(\mathrm{ppb})$ & 30 & 43 & 16 & 46 & 43 \\
$\mathrm{CO}(\mathrm{ppb})$ & 100 & 85 & 119 & 113 & 107 \\
$\mathrm{NO}(\mathrm{ppt})$ & 10 & 59 & 179 & 222 & 179 \\
$\mathrm{NO}_{2}(\mathrm{ppt})$ & 80 & 394 & 1191 & 614 & 535 \\
$\mathrm{PAN}^{(p p t)}$ & 350 & 154 & 270 & 402 & 954 \\
$\mathrm{HNO}_{3}(\mathrm{ppt})$ & 500 & 742 & 830 & 695 & 1197 \\
$\mathrm{H}_{2} \mathrm{O}_{2}(\mathrm{ppt})$ & 1500 & 1476 & 1275 & 1246 & 1370 \\
$\mathrm{HCHO}(\mathrm{ppt})$ & 310 & 491 & 804 & 1637 & 1855 \\
$\mathrm{C}_{2} \mathrm{H}_{6}(\mathrm{ppt})$ & 800 & 518 & 605 & 593 & 605 \\
$\mathrm{C}_{2} \mathrm{H}_{4}(\mathrm{ppt})$ & 10 & 27 & 87 & 68 & 45 \\
$\mathrm{C}_{3} \mathrm{H}_{6}(\mathrm{ppt})$ & 1 & 21 & 73 & 44 & 20 \\
\hline
\end{tabular}




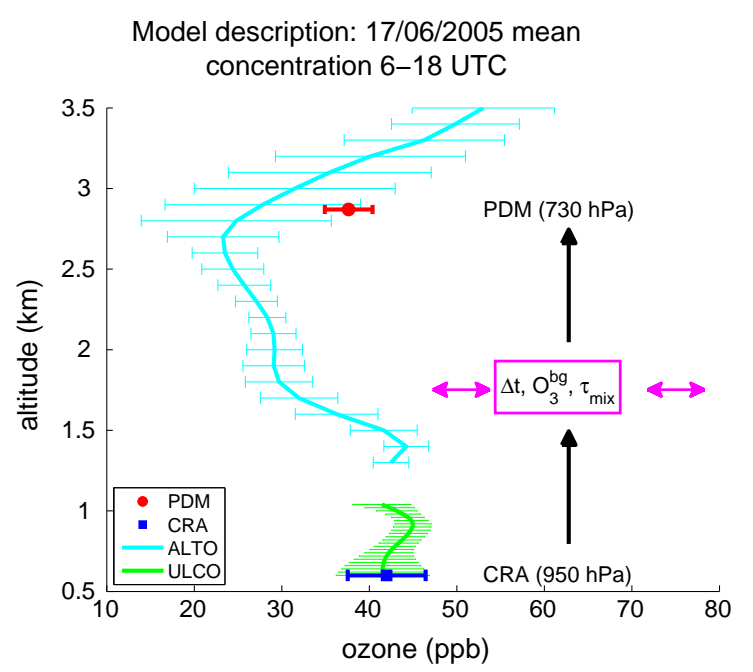

Fig. 6. Idealized model of the thermally driven upslope flow. The model box moves from CRA (950 hPa), where chemical concentrations are initialized, to PDM $(730 \mathrm{hPa})$, with adjustable travel time $(\Delta t)$. Mixing with the background atmosphere is controlled by the time constant $\left(\tau_{\text {mix }}\right)$ and the ozone background concentration $\left(\mathrm{O}_{3}^{b g}\right)$. Mean ozone concentrations between 6 and 18 UTC on June 17 for PDM (red circle), CRA (blue square), ALTO (cyan line) and ULCO (green line) with their standard deviations (bars) are displayed to support the chosen values of the ozone background concentration $\left(\mathrm{O}_{3}^{b g}\right)$.

production of $0.18 \mathrm{ppb} / \mathrm{h}$ by using a Lagrangian box model. Thus, photochemistry modelling only produces ozone and it cannot account for the observed ozone minimum at midday.

For the boundary layer, the ozone concentration at 6 UTC at CRA is used as the initial condition (Fig. 5b and Table 2). The model produces a $20 \mathrm{ppb}$ increase between 6 UTC and 17 UTC at CRA. Even if ozone production is much more efficient in the boundary layer than in the free troposphere, the modelled ozone time series stays below the measurements. This supports the idea of entrainment of the ozone-rich residual layer (Fig. 4) within the boundary layer in the early morning, as mentioned before (Section 3). Clearly, photochemical modelling cannot account for ozone time series, both at PDM and CRA on June 17. Mixing processes have to be considered.

\subsubsection{Chemistry and transport without mixing}

We now focus on ozone time series at PDM between 10 UTC and 18 UTC (maximum of boundary layer influence). A series of simulations was performed, initialized hourly with the ozone concentrations at CRA (Table 2). The simulation for the travel time of five hours is presented in Fig. 7 (magenta diamonds). No mixing was considered between the air parcel and the background atmosphere. Compared with observations, modelled ozone mixing ratios at PDM are overestimated by more than $10 \mathrm{ppb}$. This is also the case by adjusting the travel time between 3 and 7 h (not shown). Air masses transported from boundary layer to PDM, even including photochemical ageing, must experience some mixing.

\subsubsection{Transport and mixing without chemistry}

Here again, a similar series of simulations was performed, initialized hourly with the ozone concentrations at CRA
(Table 2). But this time, chemistry was switched off during transport and mixing was taken into account. Fig. 7 presents the results for $\tau_{\text {mix }}=6 \mathrm{~h}$ and $\mathrm{O}_{3}^{b g}=30 \mathrm{ppb}$ (blue circles). The agreement with the observations at PDM is significantly closer. This reveals that initial ozone concentrations at CRA (driven by photochemical production and entrainment within the boundary layer) and mixing with tropospheric air masses during vertical transport are the two main contributions which account for ozone levels at PDM in presence of anabatic transport.

\subsubsection{All processes and estimation of $f$}

Combining transport, photochemistry and mixing, the modelled ozone concentrations (Fig. 7 and Table 2) are now the closest to the observed concentrations (green squares). Comparison with the former two simulations shows that photochemistry during vertical anabatic transport increases ozone levels by $3 \mathrm{ppb}$, while mixing with tropospheric air masses decreases ozone by $10 \mathrm{ppb}$ in the same time. Given the values of $\tau_{\text {mix }}$ and $\Delta t$ used for this simulation, the air mass sampled at PDM is composed of $43 \%$ of boundary layer air $(f=0.43)$ and $57 \%$ of free tropospheric air.

Further calculations (not shown) have been made to test the sensitivity of the match between modelled and observed ozone mixing ratio to the three parameters of the model: travel time $\Delta t$,

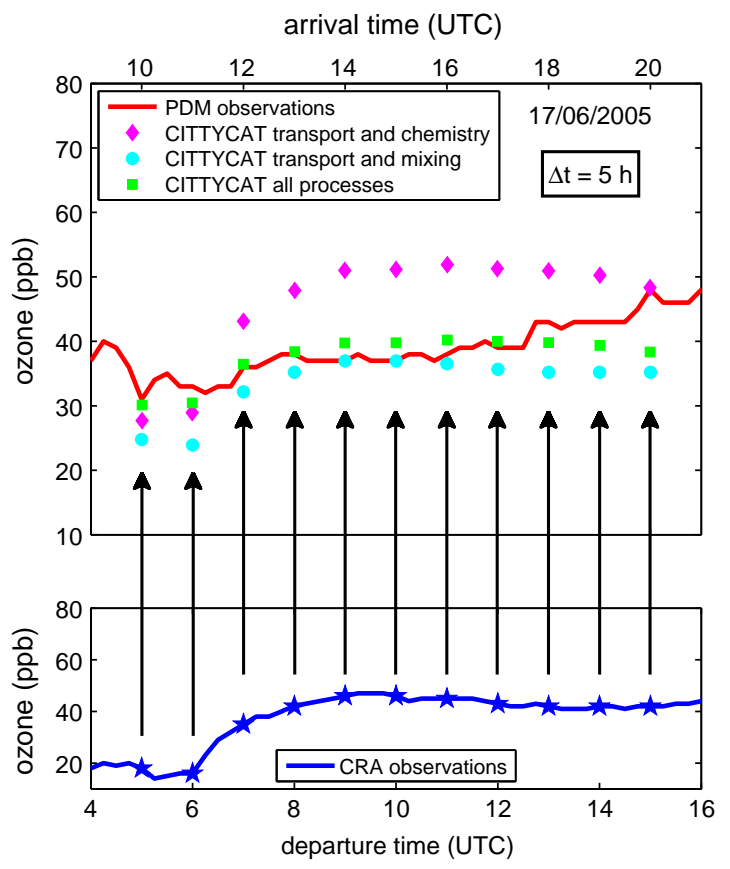

Fig. 7. Ozone mixing ratio time series computed for June 17 with a travel time of $5 \mathrm{~h}$, a mixing time of $6 \mathrm{~h}$ (for relevant simulations) and an ozone background value of $30 \mathrm{ppb}$ (for relevant simulations). Black vertical arrows link the departure time at CRA to the arrival time at PDM. Blue stars show initial ozone values, taken from ozone measurements at CRA on June 17 (blue line). Magenta diamonds, blue circles and green squares show the result of the simulation at PDM, respectively with chemical processes only, mixing process only and chemical and mixing processes taken into account by the model during transport. The red line shows ozone measurements at PDM. 
mixing time $\tau_{\text {mix }}$ and ozone background value $\mathrm{O}_{3}^{\text {gg }}$. A close match is still found for travel times ranging from 4 to $7 \mathrm{~h}$, mixing times from 3 to $9 \mathrm{~h}$ and ozone background values from 25 to $35 \mathrm{ppb}$. The mixing time $\left(\tau_{\text {mix }}\right)$ is used here as a free parameter and is not constrained by either the observations or the MesoNH model. However, previous studies using the same formulation in order to model the diffusion in the atmosphere have estimated similar values for the mixing time. Real et al. (2007) have calculated an integrated mixing time of 6.25 days that gave the closest agreement between measured and modeled CO concentrations, while Arnold et al. (2007) reported dilution rates of around $0.1 \mathrm{day}^{-1}$ (meaning a mixing time of about 10 days) using successive observations of nonmethane hydrocarbons.

Combining all these uncertainties, $f$ ranges from $19 \%$ to $57 \%$. Previous studies (mainly for the Alps during the summer season) provided a similar range of values: from 15\% (Seibert et al., 1998; Zellweger et al., 2000) to 30\% (Prevot et al., 2000; Henne et al., 2005b), while Henne et al. (2005a) used a percentage of about $40 \%$ for the air export from the boundary layer in order to model the ozone chemistry above the Alps.

\section{The June 19 case study}

In order to strengthen the conclusions issued from the case study of June 17 and to further demonstrate the applicability of the model, a second IOP is examined. From the remaining 5 IOPs of the Pic 2005 campaign, the June 19 has been chosen based on the results of Gheusi et al. (2011). Due to the absence of thermal pumping or because of storm weather, it is not possible to apply this box model analysis to the June 27 or June 23 IOPs. On July 2 and 3, an ozone-rich layer is observed above CRA by the lidar at the level of PDM. It is linked to long range transport but it is not observed at PDM station. This unusual feature deserves a specific study and makes it difficult to rely on lidar measurements to account for ozone background profiles.

On June 19 the wind direction according to VHF radar at the altitude of $3 \mathrm{~km}$ was mostly NE during the morning, turning alternatively either to E or W after 12 UTC (not shown). At the PDM the evolution of wind direction during the whole day was very similar to one observed on June 17 (Fig. 2b). At both PDM and CRA, the synoptic flow is weak (wind speed below $4 \mathrm{~m} / \mathrm{s}$ ) which in turn favours the development of thermal breezes. At CRA the wind direction was W during morning turning to NW by early afternoon, with the transition starting at 5-6 UTC, and back to W during night after 20 UTC (not shown). During the whole day, the wind speed was about $5 \mathrm{~m} / \mathrm{s}$. Although, there is a cyclic change in wind direction between night and day, the evolution was very smooth in contrast to the clear diurnal cycle seen on June 17 (Fig. 2c). According to the MesoNH model, the plain-to-mountain breeze arrived at PDM by 9 UTC, the phenomenon peaked at 16 UTC and by 22 UTC the katabatic flow was well established. The combination of wind observations at CRA and model simulations suggests a travel time of 3-4 h, for the plain-to-mountain breeze to reach PDM during this day. Similar result with the travel time being about $5 \mathrm{~h}$ was found on June 17 (Section 2).

On the other hand, on June 19, the ozone observations at CRA and PDM were the highest among the six IOPs (Gheusi et al., 2011). This contrasts to 17th June when the ozone measurements at CRA and PDM were the lowest of the six IOPs. Indeed, this can be seen in Table 1 for both stations and both periods of
19/6/2005: mean concentrations 9-19 UTC

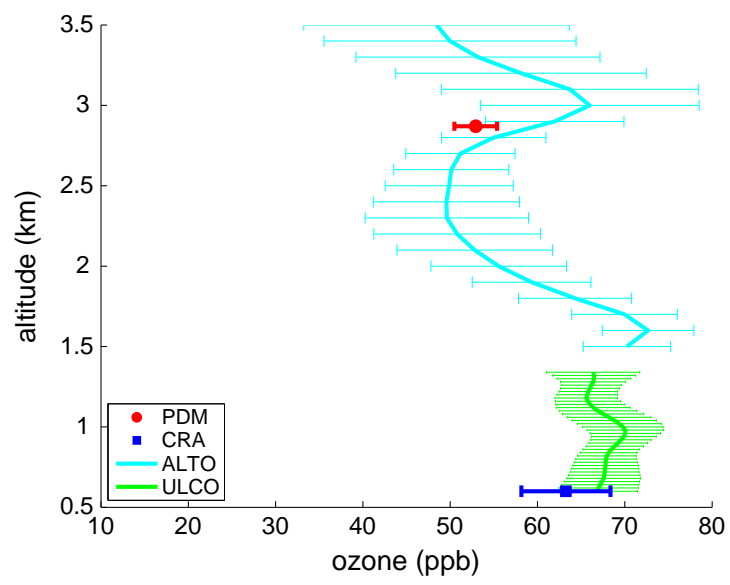

Fig. 8. As per Fig. 6 but for June 19. Note that here, the ozone concentrations are averaged between 9 and 19 UTC, when the lidars were operating.

the day. During night time on June 19, the ozone concentration at PDM was $48 \pm 6 \mathrm{ppb}$, increasing to $52 \pm 6$ during day-time, while at CRA the ozone was $51 \pm 11$ during night increasing to $62 \pm 7$, during daytime (Fig. 8). At PDM there was an opposite diurnal cycle for ozone, although less distinct than the opposite cycle of 17th June. However, this was not confirmed by the mean values during night and day in Table 1 due to high ozone concentrations of $56 \mathrm{ppb}$ which were almost constant from 16 UTC to 24 UTC (thus even after sunset). The ozone decreased

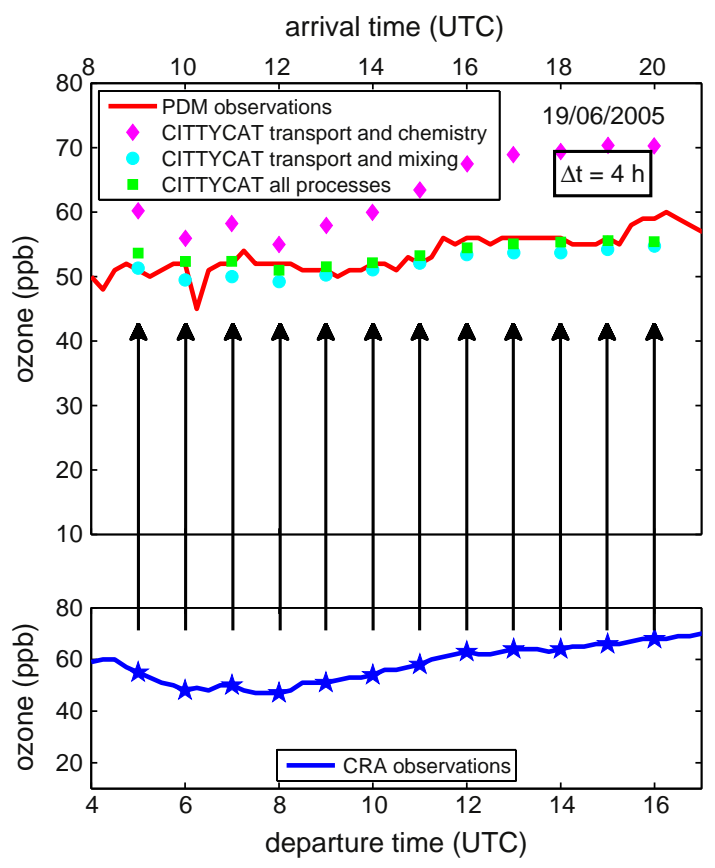

Fig. 9. As per Fig. 7 but for June 19. Here, the travel time is $4 \mathrm{~h}$, the mixing time is $3 \mathrm{~h}$ (for relevant simulations) and the ozone background value is $50 \mathrm{ppb}$ (for relevant simulations). 
slightly by 3 ppb after 7 UTC, remaining almost constant to 51 ppb until 14 UTC (not shown). At CRA the ozone diurnal cycle was almost typical with high concentrations during the daytime (over 65 ppb between 14 and 18 UTC), but with a secondary ozone peak of $65 \mathrm{ppb}$ during the night ( 3 UTC), suggesting the advection of a polluted air mass. Part of the ozone time series at both stations for this day can be seen in Fig. 9. The vertical distribution of ozone for this IOP ( similar to Fig. 4a), measured by ALTO and ULCO, can be found in the study of Gheusi et al. (2011, see their Fig. 11). The mean ozone profile averaged over 9-19 UTC is presented in Fig. 8. It can be observed that during daytime the ozone up to $2 \mathrm{~km}$ was above $60 \mathrm{ppb}$, decreasing to $50 \mathrm{ppb}$ in the altitude range $2.2-2.7 \mathrm{~km}$ a.s.l. The peak at $3 \mathrm{~km}$ was produced by an ozone rich layer $(>80 \mathrm{ppb})$ measured at about 12 UTC. During June 19 the boundary layer over CRA did not develop over $1.9 \mathrm{~km}$, as indicated by ALTO backscatter ratio (not shown). Similar to observations of June 17, this means that PDM ozone observations are not directly connected to ozone concentrations within the boundary layer over the plain.

As in the case of June 17, we are using the model developed in the previous section in order to simulate the plain-to-mountain breeze and its impact on ozone observations at PDM. Fig. 9 shows the case considering only the transport and the chemistry (magenta diamonds). The travel time is $4 \mathrm{~h}$, as indicated by the onset of plain-to-mountain breeze at CRA by the wind direction change and the arrival of the breeze at PDM by MesoNH. Again, the ozone observations at CRA are used for the initialization of the model. Clearly, this case overestimates the ozone observations at PDM by 4 up to $15 \mathrm{ppb}$. By considering only the transport and the mixing with the free-troposphere (blue circles), the results of the model agree closer with the ozone observations at PDM within $3 \mathrm{ppb}$ (Fig. 9). The ozone background concentration is set to $50 \mathrm{ppb}$, according to ALTO measurements in the free troposphere, while the mixing time is $3 \mathrm{~h}$. When taking into account all processes (transport, mixing and chemistry), the results of the model match almost perfectly the observations at PDM from 10 to 19 UTC. The best match is achieved for the mixing time of $3 \mathrm{~h}$ and total travel time of $4 \mathrm{~h}$, thus $f=0.26$ (Eq. (4)). This indicates that the air mass sampled at PDM on June 19 is composed of $26 \%$ of the boundary layer and $74 \%$ of free tropospheric air. Good agreement between model results and ozone at PDM is found for ozone background concentration 45-50 ppb, total travel time 2-6 h and mixing time 3-9 h. For these values, $f$ varies from 0.14 to 0.57 , which is close to values found for the case of June 17 ( $f=0.19-0.57$ ).

\section{Conclusions and perspectives}

In situ measurements of trace gases and aerosols at mountain stations can be influenced by upward transport of boundary layer air masses. In this study, ozone observations at PDM on June 17 and 192005 have been investigated. On both days a thermal circulation developed in the morning. It brought air masses from CRA (plain) up to PDM (summit) late in the morning and in the afternoon. A Lagrangian box model, including chemistry and mixing, has been used to account for transport from CRA to PDM. It was initialized with ozone observations at CRA. A measured ozone vertical profile provided background values in the free troposphere. The model captured the time evolution of ozone mixing ratio observed at PDM, when it is under the influence of this thermal circulation. It also estimated the fraction of free tropospheric air sampled at PDM.

The following scenario quantitatively accounts for ozone measurements at PDM. In the morning, the ozone mixing ratio increases at CRA not only due to photochemical production in the boundary layer, but also due to mixing with an elevated (above but close to the boundary layer) ozone-rich residual layer. At the same time a thermal plain-to-mountain circulation develops. Air masses from the boundary layer over the plain are transported to PDM in about 3-5 h (depending on the day). During transport, 2-3 ppb of ozone is photochemically produced, but a large fraction (43 to $86 \%$ ) of ozone-poor air is incorporated from the free troposphere. Or, in other words, 14 to $57 \%$ of air masses measured at PDM are transported from the piedmont region. These fractions are in line with former studies.

It would now be useful to extend this modelling approach to a larger dataset to further investigate its robustness. To do this, in situ ozone measurements and vertical profiles are required. Mixing processes would also be better constrained if measurements of other trace gases, including their vertical profiles, are available. This study also shows that in situ measurements at PDM are not only influenced by daily ozone production in the lowland boundary layer, but also by ozone residual layers. It would thus be interesting to investigate to what extent a network of high altitude stations, combined with ozone surface measurements and ozone vertical profiles, could be used to monitor boundary layer mass injection in the free troposphere.

\section{Acknowledgements}

We thank G. Curci for providing the MM5 data to drive CHIMERE simulations and E. Real for the assistance regarding CITTYCAT. B. Campistron is acknowledged for providing the VHF radar data. We similarly thank the reviewers for helping us to improve the quality of our paper and $\mathrm{C}$. Burrows for correcting grammatical mistakes. C. Tsamalis is grateful to A. G. Leventis Foundation for financial support.

\section{References}

Ancellet, G., Ravetta, F., 1998. Compact airborne lidar for tropospheric ozone: description and field measurements. Appl. Opt. 37 (24), 5509-5521.

Ancellet, G., Ravetta, F., 2003. On the usefulness of an airborne lidar for $\mathrm{O}_{3}$ layer analysis in the free troposphere and the planetary boundary layer. J. Environ. Monit. 5, 47-56.

Ancellet, G., Ravetta, F., 2005. Analysis and validation of ozone variability observed by lidar during the ESCOMPTE - 2001 campaign. Atmos. Res. 74, 435-459.

Aneja, V.P., Claiborn, C.S., Li, Z., Murthy, A., 1994. Trends, seasonal variations and analysis of high-elevation surface nitric acid, ozone and hydrogen peroxide. Atmos. Environ. 28 (10), 1781-1790.

Arnold, S.R., Methven, J., Evans, M.J., Chipperfield, M.P., Lewis, A.C., Hopkins, J.R., McQuaid, J.B., Watson, N., Purvis, R.M., Lee, J.D., Atlas, E.L., Blake, D.R., Rappengluck, B., 2007. Statistical inference of OH concentrations and air mass dilution rates from successive observations of nonmethane hydrocarbons in single air masses. J. Geophys. Res. 112, D10S40.

Atlas, E.L., Ridley, B.A., 1996. The Mauna Loa observatory photochemistry experiment: introduction. J. Geophys. Res. 101 (D9), 14531-14541.

Baltensperger, U., Gaggeler, H.W., Jost, D.T., Lugauer, M., Schwikowski, M., Weingartner, E., Seibert, P., 1997. Aerosol climatology at the high-alpine site Jungfraujoch, Switzerland. J. Geophys. Res. 102 (D16), 19707-19715.

Bonasoni, P., Stohl, A., Cristofanelli, P., Calzolari, F., Colombo, T., Evangelisti, F. 2000. Background ozone variations at Mt. Cimone station. Atmos. Environ. 34, 5183-5189.

Bossert, J.E., Cotton, W.R., 1994. Regional-scale flows in mountainous terrain. Part I: a numerical and observational comparison. Mon. Weather Rev. 122, 1449-1471. 
Campistron, B., Pointin, Y.B., Lohou, F., Pages, J.-P., 1999. Aspect sensitivity of VHF radar echoes observed in the middle and upper troposphere during the passage of a cut-off low. Radio Sci. 34 (3), 667-679.

Chevalier, A., 2007. Développement du service d'observation PAES: pollution atmosphèrique à l'échelle synoptique, bilan de l'ozone dans la troposphère libre. (Ph.D. thesis) Université Toulouse III - Paul Sabatier, France.

Chevalier, A., Gheusi, F., Delmas, R., Ordonez, C., Sarrat, C., Zbinden, R., Thouret, V., Athier, G., Cousin, J.-M., 2007. Influence of altitude on ozone levels and variability in the lower troposphere: a ground-based study for western Europe over the period 2001-2004. Atmos. Chem. Phys. 7, 4311-4326 (URL www.atmos-chem-phys.net/7/4311/2007/)

CNRS, 2009. Meso-NH scientific documentation. Tech. rep., Météo France-CNRS (URL http://mesonh.aero.obs-mip.fr/mesonh/).

Couach, O., Balin, I., Jimenez, R., Ristori, P., Perego, S., Kirchner, F., Simeonov, V., Calpini, B., van den Bergh, H., 2003. An investigation of ozone and planetary boundary layer dynamics over the complex topography of Grenoble combining measurements and modeling. Atmos. Chem. Phys. 3, 549-562 (URL www.atmos-chem-phys.org/acp/3/549/).

de Wekker, S.F.J., Zhong, S., Fast, J.D., Whiteman, C.D., 1998. A numerical study of the thermally driven plain-to-basin wind over idealized basin topographies. J. Appl. Meteorol. 37, 606-622.

Delbarre, H., Augustin, P., Said, F., Campistron, B., Benech, B., Lohou, F., Puygrenier, V., Moppert, C., Cousin, F., Freville, P., Frejafon, E., 2005. Ground-based remote sensing observation of the complex behaviour of the Marseille boundary layer during ESCOMPTE. Atmos. Res. 74, 403-433.

Dubosclard, G., Benech, B., Noilhan, J., Druilhet, A., 1983. Etude expérimentale de la couche limite au dessus d'un relief modéré proche d'une chaîne de montagne. Partie III: Structure turbulente de la couche limite convective au voisinage du sol analysée par sondage acoustique. Bound.-Layer Meteorol. $25,107-119$.

Evans, M.J., Shallcross, D.E., Law, K.S., Wild, J.O.F., Simmonds, P.G., Spain, T.G., Berrisford, P., Methven, J., Lewis, A.C., McQuaid, J.B., Pilling, M.J., Bandy, B.J. Penkett, S.A., Pyle, J.A., 2000. Evaluation of a Lagrangian box model using field measurements from EASE (Eastern Atlantic Summer Experiment) 1996. Atmos. Environ. 34, 3843-3863.

Fischer, H., Nikitas, C., Parchatka, U., Zenker, T., Harris, G.W., Matuska, P., Schmitt, R., Mihelcic, D., Muesgen, P., Paetz, H.-W., Schultz, M., VolzThomas, A., 1998. Trace gas measurements during the Oxidizing Capacity of the Tropospheric Atmosphere campaign 1993 at Izana. J. Geophys. Res. 103 (D11), 13505-13518.

Fischer, H., Kormann, R., Klupfel, T., Gurk, C., Konigstedt, R., Parchatka, U., Muhle, J., Rhee, T.S., Brenninkmeijer, C.A.M., Bonasoni, P., Stohl, A., 2003. Ozone production and trace gas correlations during the June 2000 MINATROC intensive measurement campaign at Mt. Cimone. Atmos. Chem. Phys. 3, 725-738 (URL www.atmos-chem-phys.org/acp/3/725/).

Forrer, J., Ruttimann, R., Schneiter, D., Fischer, A., Buchmann, B., Hofer, P., 2000. Variability of trace gases at the high-Alpine site Jungfraujoch caused by meteorological transport processes. J. Geophys. Res. 105 (D10), 12241-12251.

Gheusi, F., Ravetta, F., Delbarre, H., Tsamalis, C., Chevalier, A., Leroy, C., Augustin, P. , Delmas, R., Ancellet, G., Athier, G., Bouchou, P., Campistron, B., Cousin, J.-M., Fourmentin, M., Meyerfeld, Y., 2011. Pic 2005, a field campaign to investigate low-tropospheric ozone variability in the Pyrenees. Atmos. Res. 101, 640-665.

Haiden, T., 2003. On the pressure field in the slope wind layer. J. Atmos. Sci. $60,1632-1635$

Henne, S., Furger, M., Nyeki, S., Steinbacher, M., Neininger, B., de Wekker, S.F.J., Dommen, J., Spichtinger, N., Stohl, A., Prevot, A.S.H., 2004. Quantification of topographic venting of boundary layer air to the free troposphere. Atmos. Chem. Phys. 4, 497-509 (URL www.atmos-chem-phys.org/acp/4/497/).

Henne, S., Dommen, J., Neininger, B., Reimann, S., Staehelin, J., Prevot, A.S.H. 2005a. Influence of mountain venting in the Alps on the ozone chemistry of the lower free troposphere and the European pollution export. J. Geophys. Res. 110, D22307.

Henne, S., Furger, M., Prevot, A.S.H., 2005b. Climatology of mountain venting induced elevated moisture layers in the lee of the Alps. J. Appl. Meteorol. 44, 620-633.

Henne, S., Klausen, J., Junkermann, W., Kariuki, J.M., Aseyo, J.O., Buchmann, B., 2008. Representativeness and climatology of carbon monoxide and ozone at the global GAW station Mt. Kenya in equatorial Africa. Atmos. Chem. Phys. 8, 3119-3139 (URL www.atmos-chem-phys.net/8/3119/2008/)

Henne, S., Brunner, D., Folini, D., Solberg, S., Klausen, J., Buchmann, B., 2010 Assessment of parameters describing representativeness of air quality insitu measurement sites. Atmos. Chem. Phys. 10, 3561-3581 (URL www. atmos-chem-phys.net/10/3561/2010/)

Kalabokas, P.D., Viras, L.G., Bartzis, J.G., Repapis, C.C., 2000. Mediterranean rural ozone characteristics around the urban area of Athens. Atmos. Environ. 34, 5199-5208.

Kimura, F., Kuwagata, T., 1993. Thermally induced wind passing from plain to basin over a mountain range. J. Appl. Meteorol. 32, 1538-1547.
Kleinman, L., Lee, Y.-N., Springston, S.R., Nunnermacker, L., Zhou, X., Brown, R., Hallock, K., Klotz, P., Leahy, D., Lee, J.H., Newman, L., 1994. Ozone formation at a rural site in the southeastern United States. J. Geophys. Res. 99 (D2), 3469-3482.

Langford, A.O., Senff, C.J., Alvarez II, R.J., Banta, R.M., Hardesty, R.M., 2010. Long-range transport of ozone from the Los Angeles basin: a case study. Geophys. Res. Lett. 37, L06807.

Lesouef, D., Gheusi, F., Delmas, R., Escobar, J., 2011. Numerical simulations of local circulations and pollution transport over Reunion Island. Ann. Geophys. 29, 53-69 (URL www.ann-geophys.net/29/53/2011/).

Lugauer, M., Baltensperger, U., Furger, M., Gaggeler, H.W., Jost, D.T., Nyeki, S., Schwikowski, M., 2000. Influences of vertical transport and scavenging on aerosol particle surface area and radon decay product concentrations at the Jungfraujoch (3454 m above sea level). J. Geophys. Res. 105 (D15), 19869-19879.

Macdonald, A.M., Anlauf, K.G., Leaitch, W.R., Chan, E., Tarasick, D.W., 2011. Interannual variability of ozone and carbon monoxide at the Whistler high elevation site: 2002-2006. Atmos. Chem. Phys. 11, 11431-11446 (URL http://www.atmos-chem-phys.net/11/11431/2011/).

Marenco, A., 1986. Variations of $\mathrm{CO}$ and $\mathrm{O}_{3}$ in the troposphere: evidence of $\mathrm{O}_{3}$ photochemistry. Atmos. Environ. 20 (5), 911-918.

Mendonca, B.G., 1969. Local wind circulation on the slopes of Mauna Loa. J. Appl. Meteorol. 8, 533-541.

Menut, L., Flamant, C., Pelon, J., Flamant, P.H., 1999. Urban boundary layer height determination from lidar measurements over the Paris area. Appl. Opt. 38 (6), 945-954.

Millan, M.M., Mantilla, E., Salvador, R., Carratala, A., Sanz, M.J., Alonso, L., Gangoiti, G., Navazo, M., 2000. Ozone cycles in the western Mediterranean basin: interpretation of monitoring data in complex coastal terrain. J. Appl. Meteorol. 39, 487-508.

Naja, M., Lal, S., Chand, D., 2003. Diurnal and seasonal variabilities in surface ozone at a high altitude site $\mathrm{Mt}$ Abu $\left(24.6^{\circ} \mathrm{N}, 72.7^{\circ} \mathrm{E}, 1680 \mathrm{~m}\right.$ asl $)$ in India. Atmos. Environ. 37, 4205-4215.

Neu, U., Kunzle, T., Wanner, H., 1994. On the relation between ozone storage in the residual layer and daily variation in near-surface ozone concentration - a case study. Bound.-Layer Meteorol. 69, 221-247.

Noilhan, J., Benech, B., Druilhet, A., Dubosclard, G., 1982. Etude expérimentale de la couche limite au dessus d'un relief modéré proche d'une chaîne de montagne. Partie I: Influence sur l'écoulement du relief à moyenne et grande échelles. Bound.-Layer Meteorol. 24, 395-414.

Oltmans, S.J., Levy II, H., 1994. Surface ozone measurements from a global network. Atmos. Environ. 28 (1), 9-24.

Prevot, A.S.H., Dommen, J., Baumle, M., 2000. Influence of road traffic on volatile organic compound concentrations in and above a deep Alpine valley. Atmos. Environ. 34, 4719-4726.

Rampanelli, G., Zardi, D., Rotunno, R., 2004. Mechanisms of up-valley winds. J. Atmos. Sci. 61, 3097-3111.

Ravetta, F., Ancellet, G., Colette, A., Schlager, H., 2007. Long-range transport and tropospheric ozone variability in the western Mediterranean region during the Intercontinental Transport of Ozone and Precursors (ITOP-2004) campaign. J. Geophys. Res. 112, D10S46.

Real, E., Law, K.S., Weinzier, B., Fiebig, M., Petzold, A., Wild, O., Methven, J., Arnold, S., Stohl, A., Huntrieser, H., Roiger, A., Schlager, H., Stewart, D., Avery, M., Sachse, G., Browell, E., Ferrare, R., Blake, D., 2007. Processes influencing ozone levels in Alaskan forest fire plumes during long-range transport over the North Atlantic. J. Geophys. Res. 112, D10S46.

Rouil, L., Honore, C., Vautard, R., Beekmann, M., Bessagnet, B., Malherbe, L., Meleux, F., Dufour, A., Elichegaray, C., Flaud, J.-M., Menut, L., Martin, D., Peuch, A., Peuch, V.-H., Poisson, N., 2009. PREV'AIR: an operational forecasting and mapping system for air quality in Europe. Bull. Am. Meteorol. Soc. 90, 73-83.

Schuepbach, E., Friedli, T.K., Zanis, P., Monks, P.S., Penkett, S.A., 2001. State space analysis of changing seasonal ozone cycles (1988-1997) at Jungfraujoch (3580 in above sea level) in Switzerland. J. Geophys. Res. 106 (D17), 20413-20427.

Schumann, U., 1990. Large-eddy simulation of the up-slope boundary layer. Q. J. R. Meteorol. Soc. 116, 637-670.

Seibert, P., Kromp-Kolb, H., Kasper, A., Kalina, M., Puxbaum, H., Jost, D.T., Schwikowski, M., Baltensperger, U., 1998. Transport of polluted boundary layer air from the Po Valley to high-alpines sites. Atmos. Environ. 32 (23), 3953-3965.

Seibert, P., Beyrich, F., Gryning, S.-E., Joffre, S., Rasmussen, A., Tercier, P., 2000. Review and intercomparison of operational methods for the determination of the mixing height. Atmos. Environ. 34, 1001-1027.

Shaw, G.E., 2007. Aerosols at a mountaintop observatory in Arizona. J. Geophys. Res. 112, D07206.

Szintai, B., Kaufmann, P., Rotach, M.W., 2010. Simulation of pollutant transport in complex terrain with a numerical weather prediction-particle dispersion model combination. Bound.-Layer Meteorol. 137, 373-396. 
Vautard, R., Beekmann, M., Roux, J., Gombert, D., 2001. Validation of a hybrid forecasting system for the ozone concentrations over the Paris area. Atmos. Environ. 35, 2449-2461.

Vergeiner, I., Dreiseitl, E., 1987. Valley winds and slope winds - observations and elementary thoughts. Meteorog. Atmos. Phys. 36, 264-286.

Vosper, S., Carter, E., Lean, H., Lock, A., Clark, P., Webster, S., 2013. High resolution modelling of valley cold pools. Atmos. Sci. Lett. 14, 193-199.

Weissmann, M., Braun, F.J., Gantner, L., Mayr, G.J., Rahm, S., Reitebuch, O., 2005. The Alpine mountain-plain circulation: Airborne Doppler lidar measurements and numerical simulations. Mon. Weather Rev. 133, 3095-3109.

Whiteman, C. 1990. Observation of thermally developed wind systems in mountainous terrain. In: Blumen, W. (Ed.), Atmospheric Processes over Complex Terrain. American Meteorological Society, Boston, USA, pp. 5-42 (Ch. 2).

Whiteman, C.D., 2000. Mountain Meteorology, Fundamentals and Applications. Oxford University Press, New York, USA

Wild, O., Law, K.S., McKenna, D.S., Bandy, B.J., Penkett, S.A., Pyle, J.A., 1996. Photochemical trajectory modeling studies of the North Atlantic region during August 1993. J. Geophys. Res. 101 (D22), 29269-29288.

Zanis, P., Monks, P.S., Schuepbach, E., Penkett, S.A., 2000. The role of in situ photochemistry in the control of ozone during spring at the Jungfraujoch
(3,580 $\mathrm{m}$ asl $)$ - comparison of model results with measurements. J. Atmos. Chem. 37, 1-27.

Zaveri, R.A., Saylor, R.D., Peters, L.K., McNider, R., Song, A., 1995. A model investigation of summertime diurnal ozone behavior in rural mountainous locations. Atmos. Environ. 29 (9), 1043-1065.

Zellweger, C., Ammann, M., Buchmann, B., Hofer, P., Lugauer, M. Ruttimann, R., Streit, N., Weingartner, E., Baltensperger, U., 2000. Summertime $\mathrm{NO}_{y}$ speciation at the Jungfraujoch, $3580 \mathrm{~m}$ above sea level, Switzerland. J. Geophys. Res. 105 (D5), 6655-6667.

Zellweger, C., Forrer, J., Hofer, P., Nyeki, S., Schwarzenbach, B., Weingartner, E., Ammann, M., Baltensperger, U., 2003. Partitioning of reactive nitrogen $\left(\mathrm{NO}_{y}\right)$ and reactive dependence on meteorological conditions in the lower free troposphere. Atmos. Chem. Phys. 3, 779-796 (URL http://www.atmos-chemphys.net/3/779/2003/).

Zhang, J., Rao, S.T., 1999. The role of vertical mixing in the temporal evolution of ground-level ozone concentrations. J. Appl. Meteorol. 38, 1674-1691.

Zyrichidou, I., Koukouli, M.E., Balis, D.S., Kioutsioukis, I., Poupkou, A., Katragkou, E., Melas, D., Boersma, K.F., van Roozendael, M., 2013. Evaluation of high resolution simulated and $\mathrm{OMI}$ retrieved tropospheric $\mathrm{NO}_{2}$ column densities over Southeastern Europe. Atmos. Res. 122, 55-66. 